\title{
Research Article \\ Epitheliotrophic Cutaneous T Cell Lymphoma (CETL) in a Labrador Retriever Dog. A Case Report
}

\author{
Maria S. Gonzalez-Domingez, Sara P. Carmona A. and Rodrigo Restrepo \\ CES University, Medellín, Colombia
}

Correspondence should be addressed to: Maria S. Gonzalez-Domingez; mgonzalez@ces.edu.co

Received 18 July 2013; Accepted 10 October 2013; Published 24 January 2014

Academic Editor: Hiroki Sakai

Copyright (C 2014 Maria S. Gonzalez-Domingez, Sara P. Carmona A. and Rodrigo Restrepo. Distributed under Creative Commons CC-BY 3.0

\begin{abstract}
A female 7 years old Labrador retriever was attended with a severe dermatological disease. The dog was treated with cephalexin $(25 \mathrm{mg} / \mathrm{kg} / 12 \mathrm{~h} / 10$ days $)$, chlorhexidine shampoo and nutraceuticals (Omega 3, vitamins and minerals), with no clinical improvement. The clinical and histopathology results suggested a diagnosis of mycosis fungoides. Accordingly, treatment schedule was changed, but the dog did not show any clinical remission after several days under treatment and died. Immunohistochemistry evidenced a severe infiltration of CD3 T-cells collected around the basal squamous epithelia. Immunohistochemistry results confirmed the first mycosis fungoides case report in Colombia. Clinical findings and the most relevant treatment schedules are discussed.
\end{abstract}

Keywords: Mycosis fungoides, neoplasia, Sezary syndrome.

\section{Introduction}

Epitheliotrophic Cutaneous T-Cell Lymphoma (CETL) is a rare malignant neoplasia of unknown origin affecting dogs and cats (Ackerman, 2008; Fontaine et al., 2010); It is commonly associated with an activation of cytotoxic CD8+ T-cells (Ackerman, 2008; Fogel and Manzuc, 2009; Hnilica and Medleau, 2011; Medleau et al., 2003; Scott et al., 2001) seeping into superficial dermis and epidermis, causing thickening, hyperkeratosis, plaque forming and ulcers (Harvey and McKeever, 2001). CETL is a common finding in elderly dogs (Ackerman, 2008; Medleau et al., 2003; Scott et al., 2001), and the disease shows no predilection for gender or breed
(Fontaine et al., 2009; Harvey and McKeever, 2001; Scott et al., 2001). Mycosis fungoides, with its associated leukemia (Fogel and Manzuc, 2009), Sezary syndrome and pagetoid reticulosis (Ackerman, 2008; Scott et al., 2001) are considered the most frequent forms of CETL in canines. The disease also presents a clinical form common to dogs and cats, characterized by a pruritic and ulcerative dermatitis (Ackerman, 2008; Harvey and McKeever, 2001) refractory to systemic glucocorticoid treatment (Harvey and McKeever, 2001) which can progress toward plaque-forming erythrodermia (Ackerman, 2008; Harvey and McKeever, 2001). Skin nodules (that can be formed along the tumoral phase of the disease)

Cite this Article as: Maria S. Gonzalez-Domingez, Sara P. Carmona A. and Rodrigo Restrepo (2014), "Epitheliotrophic Cutaneous T Cell Lymphoma (CETL) in a Labrador Retriever Dog. A Case Report," International Journal of Veterinary Medicine: Research \& Reports, Vol. 2014 (2014), Article ID 322113, DOI: $10.5171 / 2014.322113$ 
and/or ulcers are also found in late clinical stages of the disease (Harvey and McKeever, 2001). In these cases, a lymphadenomegaly related to a systemic generalized disease, including the presence of T-cell lymphoma (Sezary syndrome) is found (Ackerman, 2008; Scott et al., 2001). This is the first clinical case of a dog affected by CETL reported in Colombia. The definite diagnosis was based on clinical symptoms and a CD3 T-cell compromise evidenced by immunohistochemistry.

\section{Case Report}

\section{Individual Information}

A female 7-year-old Labrador retriever was attended at the Small Animal Service (Centro de Medicina Veterinaria y Zootecnia, Envigado, Colombia). For the previous four months, the dog displayed dermatological symptoms without clinical remission despite several treatment schedules. At consultation, a complete vaccination and anti-parasitic record were administered to the patient. The owner reported that a clinical-based diagnosis of dermatitis had previously been established elsewhere, but the dog had not responded neither to antibiotics (cephalexin) nor antimycotic and anti-parasite treatment. A complementary medication, including omega 3 and sunflower oil supplements, chlorhexydine-containing shampoo, hydroxycin and ear washing, was established, but with no clinical remission of the disease.

\section{Clinical Findings and Complementary Diagnostic Schedules}

At clinical exam, the dog weighted $37 \mathrm{~kg}$, heart rate 112 beats/min, panting respiratory frequency, capillary refill time in 2 seconds, wet pink mucosae, $38.4{ }^{\circ} \mathrm{C}$ body temperature, normal palpable lymph nodes and body condition score 4/5. Skin appeared with multiple ulcerated exudative plaques, peeling, scab skin areas, generalized erythema, multifocal alopecia, easily detached dry hair and hyperpigmented skin (Figure 1). In addition, a severe pruritus (spontaneous and induced) was also found. Complementary laboratory testing including skin cytology (a fine needle aspiration of the cutaneous lesions) and bacterial culture with antibiogram, gram staining and trycogram was also performed. Bacterial dermatitis, dermatophytosis, dermatomycosis, and atopy with secondary bacterial contamination were considered in differential diagnosis. Laboratory results of skin samples did not neither evidenced the presence of bacteria or leukocyte infiltration nor the remaining exams, excepting the presence of cocoid microorganims. The cytology did not indicate the presence of neoplastic cells sampled area. Growth of Staphylococcus spp sensible to amikacina and resistent to trimetoprim sulfametoxazol, enrofloxacine, cefalexine, chloramphenicol and gentamicine, was detected in skin samples.

\section{Therapeutic Schedule}

The initial clinical diagnosis of the patient was of generalized superficial pyoderma, thus began the following treatment: the dog was firstly prescribed an antibiotic therapy of $25 \mathrm{mg} / \mathrm{kg} / 12 \mathrm{~h}$ cefalexin and 10 $\mathrm{mg} / \mathrm{kg} / 24 \mathrm{~h}$ rifampicin. In addition, the patient was supplemented with multivitaminics, omega 3 containing oil and sunflower oil, chlorhexydin shampoo, hydroxycin and ear wash. As the result of bacterial culture gave negative, cephalexin was withdrawn, and a treatment of 15 $\mathrm{mg} / \mathrm{kg} / 24 \mathrm{~h} / 10$ days amykacin was established by subcutaneous administration. During the treatment schedule, serial creatinine values were found within normal values (ranging from 0.85 to $1.01 \mathrm{mg} / \mathrm{dl}$ ). The owners indicated the dog presented a slight remission of symptoms consisting in partial alleviation of humid skin lesions and pruritus. At day $8^{\text {th }}$ after the treatment, the patient began to show the same clinical signs, though dry eczema and crusts, hair loss and circle alopecic areas around healing crusts were also found. Ear skin samples were taken for cytology, resulting in a diagnosis of Malassezia spp. Then, a treatment of 5 $\mathrm{mg} / \mathrm{kg} / 24 \mathrm{~h} / 21$ days ketokonazol (p.o.) was established. The results of the hemoleukogram and blood chemistry 


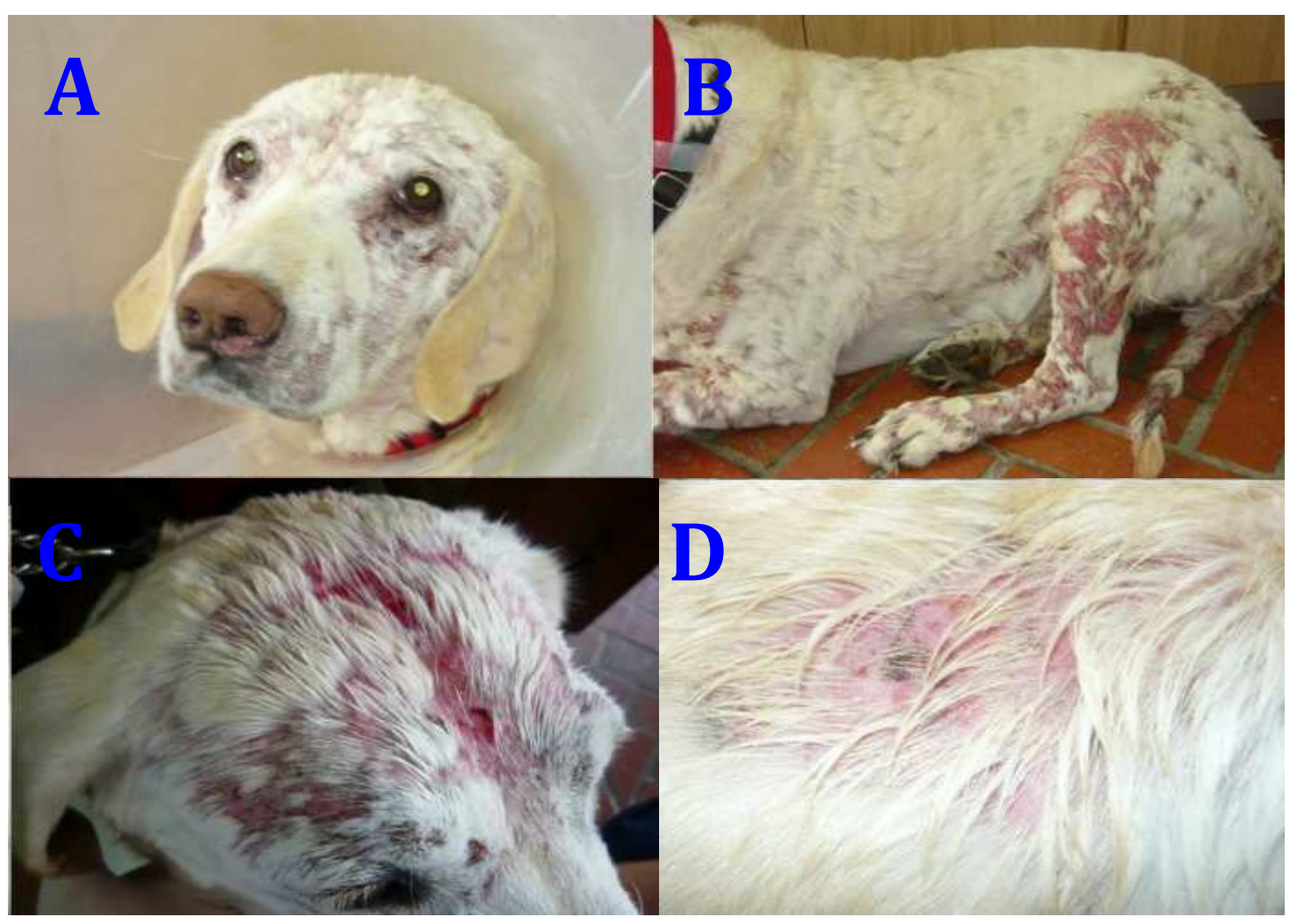

Figure 1. Clinical Aspect of the Skin at Consultation: A. Mucocutaneous Lesions in Jaws and Periorbital Areas; B. Skin Alopecia, Erythema, Eczema and Inflammation; C. Head Alopecia, Erythema, Ulceration, and Eczema; D. Alopecia and Skin Pigmentation after a Short Period of Remission.

Six days later, the owners reported an impairment of the dog's health condition, and skin lesions became wet, pruriginous and erythematous, with a generalized dermatitis. At this time, it had lost $400 \mathrm{~g}$ of body weight, and was then medicated with $12.5 \mathrm{mg} / \mathrm{kg} / 12 \mathrm{~h}$ amoxicillin clavulanate. For a 5 week period, in which the dog was not presented for clinical control, the patient was attended elsewhere by another clinician, where it was treated with 0.22 $\mathrm{mg} / \mathrm{kg}$ triamcinolone acetate, and 0,5 $\mathrm{mg} / \mathrm{kg} / 7$ days Ivermectin; skin wash with benzoyl peroxide and amitraz every 8 days, 3 doses of Inmunocel ${ }^{\circledR}$ every 2 days, and 5 $\mathrm{mg} /$ day/5 weeks prednisolone. Once was completed this schedule, the dog presented a significant improvement of skin appearance, so deciding to continue the treatment only with nutraceuticals and benzoyl peroxide shampoo.

After 20 days, the dog evidenced a severe generalized skin compromise, pruritus and erythema, and a $2 \mathrm{~cm}$ diameter mammary node was found. Then, a mammary node and a skin biopsy were taken for complementary diagnosis. In addition, a vaginal cytology test, estradiol and $\mathrm{FSH}$ measurements were recommended, as well as an ovary-hysterectomy (Table 2). The results of pre-surgical exams are presented in Tables 1 and 2 . The dog was programmed for surgical intervention, in which the mammary node and skin biopsies were taken and submitted for histopathology examination. 
Table 1. Clinical Parameter of the Dog

\begin{tabular}{|c|c|c|c|c|c|c|c|}
\hline Clinical parameter & $\begin{array}{c}\text { Value } \\
10 / 05 / 12\end{array}$ & $\begin{array}{c}\text { Value } \\
23 / 06 / 12\end{array}$ & $\begin{array}{c}\text { Value } \\
16 / 07 / 12\end{array}$ & $\begin{array}{c}\text { Value } \\
23 / 07 / 12\end{array}$ & $\begin{array}{c}\text { Value } \\
28 / 07 / 12\end{array}$ & $\begin{array}{c}\text { Value } \\
1 / 08 / 12\end{array}$ & Reference value $^{\star}$ \\
\hline Hematocrit (\%) & 48.74 & 50 & 32 & 35 & 28 & 30 & $37-55$ \\
\hline Hemoglobin (g/dl) & 16.3 & 16.8 & 10.6 & 11.2 & 9.4 & 9 & $12-18$ \\
\hline $\begin{array}{l}\text { Erythrocytes (x } \\
\left.10 / \mathrm{mm}^{3}\right)\end{array}$ & 7.28 & 7.07 & 4.66 & 5.21 & 4.18 & 4.02 & $5.5-8.5$ \\
\hline $\begin{array}{l}\text { Leukocytes }\left(\times 10^{3} /\right. \\
\left.\mathrm{mm}^{3}\right)\end{array}$ & 7010 & 10000 & 20840 & 20020 & 44400 & 50110 & $8000-14000$ \\
\hline Neutrophils (\%) & 76 & 85 & 80 & 86 & 68 & 90 & $55-75$ \\
\hline Neutrophils $(/ \mu \mathrm{l})$ & 5328 & 8500 & 16672 & 17217 & 30192 & 45099 & $3300-10000$ \\
\hline Bands (\%) & 0 & 1 & 11 & 4 & 6 & 4 & $0-3$ \\
\hline Bands (/ul) & 0 & 100 & 2292 & 801 & 2664 & 2005 & $0-300$ \\
\hline Lymphocytes (\%) & 23 & 12 & 9 & 7 & 26 & 5 & $12-30$ \\
\hline Lymphocytes $(/ \mu \mathrm{l})$ & 1612 & 1200 & 1872 & 1401 & 11544 & 2506 & $1000-4500$ \\
\hline Eosinophils (\%) & 0 & 1 & 0 & 0 & 0 & 0 & 0-10 \\
\hline Eosinophils $(/ \mu \mathrm{l})$ & 0 & 100 & 0 & 0 & 0 & 0 & $100-1500$ \\
\hline Monocytes (\%) & 1 & 1 & 0 & 3 & 0 & 1 & 41091 \\
\hline Monocytes $(/ \mu \mathrm{l})$ & 70 & 100 & 0 & 601 & 0 & 501 & $100-700$ \\
\hline Platelets $\left(\times 10^{3} / \mathrm{mm}^{3}\right)$ & 296 & 376 & 394 & 466 & 418 & 201 & $200-500$ \\
\hline Total Proteins $(\mathrm{g} / \mathrm{l})$ & 68 & 72 & 62 & 64 & 54 & 50 & $55-75$ \\
\hline
\end{tabular}

* Reference values used at Centro de Medicina Veterinaria y Zootecnia, CES University.

Table 2. Blood Chemistry of the Dog

\begin{tabular}{|c|c|c|c|c|c|c|c|}
\hline Clinical parameter & $10 / 05 / 12$ & $23 / 06 / 12$ & $7 / 07 / 12$ & $16 / 07 / 12$ & $25 / 07 / 12$ & $1 / 08 / 12$ & Reference value* \\
\hline Creatinin (mg/dl) & 0.82 & 0.91 & & 0.78 & & 0.73 & $0.5-1.5$ \\
\hline BUN (mg/dl) & 10.9 & 14.9 & & 13.2 & & $1 ., 7$ & $10-28$ \\
\hline ALP (U/L) & 153 & 86 & & 250 & & 475 & $10-73$ \\
\hline $\operatorname{ALT}(\mathrm{U} / \mathrm{L})$ & 71 & 144 & & 55 & & 206 & $21-102$ \\
\hline $\mathrm{FSH}(\mathrm{Ul} / \mathrm{ml})$ & & & & & 0,01 & & \\
\hline Estradiol ( pg/ml) & & & & & 10 & & \\
\hline Colesterol Tot $(\mathrm{mg} / \mathrm{dl})$ & & & 129 & & & & $108-266$ \\
\hline Trigliceridos (mg/dl) & & & 92 & & & & $20-112$ \\
\hline T4 Total (ug/dl) & & & 1.85 & & & & $1-3.8$ \\
\hline
\end{tabular}

\section{Postoperative Care}

Few days after surgery, the dog presented pyrexia, dyspnea, hiporexia and lethargy. The results of leukogram (Table 1, July 23) showed anemia and leukocytosis with neutrophilia. The radiographic exam of thorax showed a bronco-interstitial diffuse pulmonary pattern. Furthermore, a small and irregular alveolar focus was detected in left hemi-thorax. The patient was then hospitalized and treated with oxygen therapy, $6 \mathrm{mg} / \mathrm{kg} / 12 \mathrm{~h} / \mathrm{EV}$ imipenem and 8 mg dexamethasone. Skin and surgical lesions were also treated with $2 \%$ chlorhexidine. After four days under treatment, the patient showed a clinical remission of signs. Nevertheless, the results of leukogram (Table 1, July 28) evidenced a persistent anemia and leukocytosis, as well as a severe neutrophilia with left-deviation (Table 1, August 1). Consequently, a epitheliotrophe lymphoma was diagnosed, dying a few days later. 


\section{Histopathological and Immunohistochemical Findings} Histopathology examination was
performed on formalin-fixed paraffinembedded sections stained with hematoxylin and eosin, and Immunohistochemistry was conducted using monoclonal antibodies detecting $\mathrm{T}$ lymphocytes (CD3), working dilution 1/600. The antibodies (A0452) were obtained from DAKO Corporation (Carpinteria, CA), polyclonal antibodies (rabbit). Proteolytic digestion of the tissue was performed before Immunostaining, and monoclonal antibodies directed against human CD4 or CD8 T cells were also tested, but no signal was detected suggesting there was not cross reactivity between human and canine CD4 and/or CD8 T cell antigens.

The mammary gland tumor was classified as intraductal papillary carcinoma.
Interestingly, in the skin biopsy a lymphoproliferative lesion was found, showing a wide compromised epidermis, with abundant Pautrier's micro abscesses (Figures 2-3). A severe compromise of eccrine and pillous annexes with no associated mucinosis was found (Figure 4), evidencing atypic lymphocytes, in which the presence of granules or cytoplasmic clearing was not detected. The nucleus was small and angled, without nucleolus (Figure 5), a finding characteristic of T-cell lymphoma, mycosis fungoides type. In peripheral blood smears performed during medical evaluations, no Sezary`s cells were observed suggesting Sezary syndrome.

The results of immunohistochemistry for T-cells bearing the CD3 marker detection showed a strong signal for neoplastic Tcells in epidermis, follicular/eccrine annexes and superficial dermis (Figures 6 7).

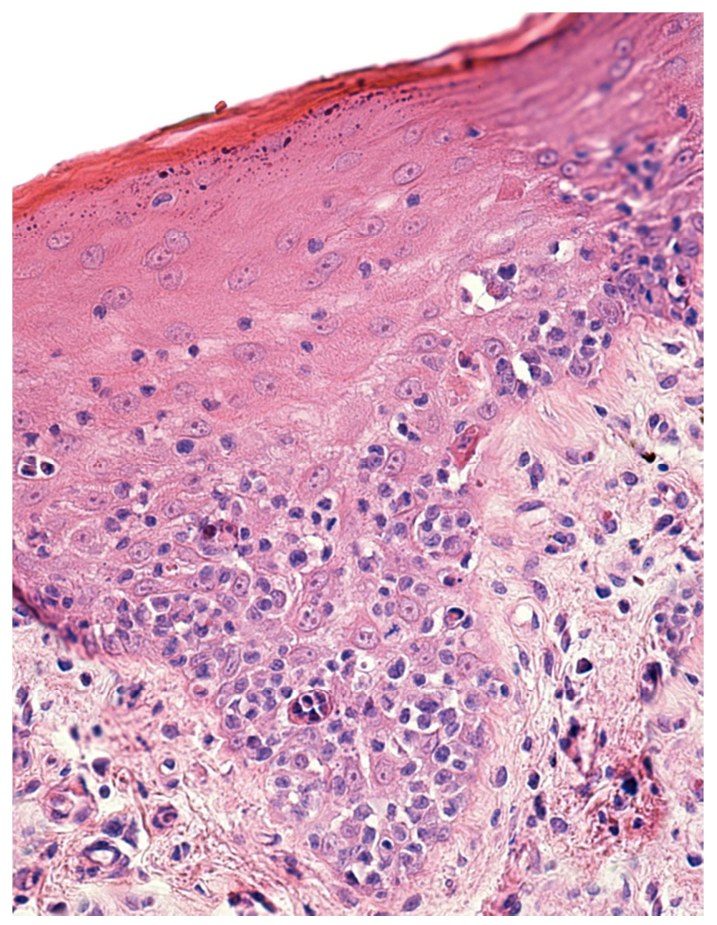

Figure 2. Epidermis with Basal Cell Infiltration, Spongiosis Unchanged (Epidermotropism). HE 200X. 


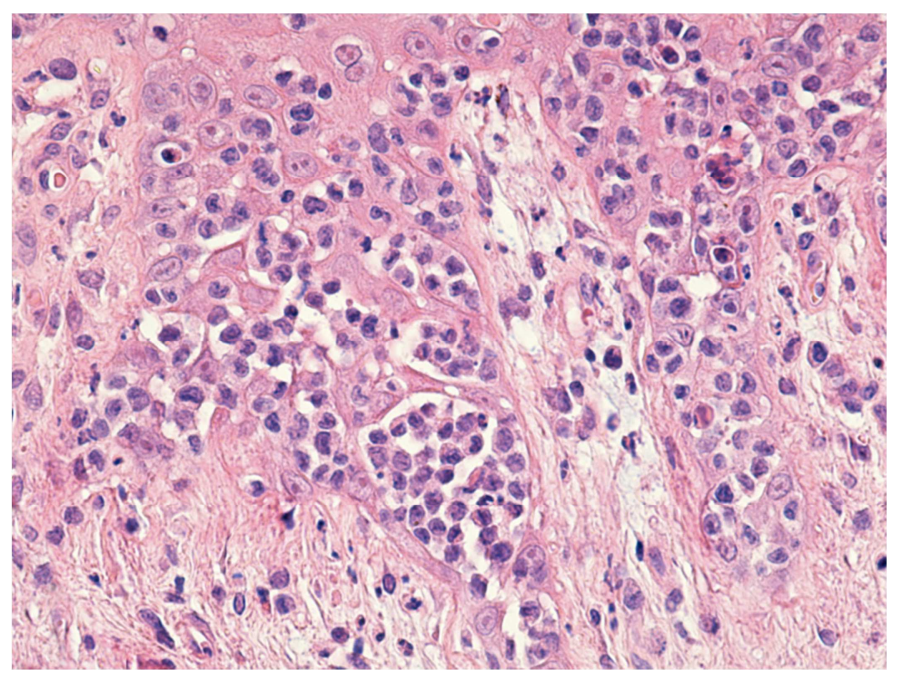

Figure 3. An Intraepidermal Collection of Atypical Lymphoid Cells Filled Microabscesses Pautrier Setting. HE 200X.

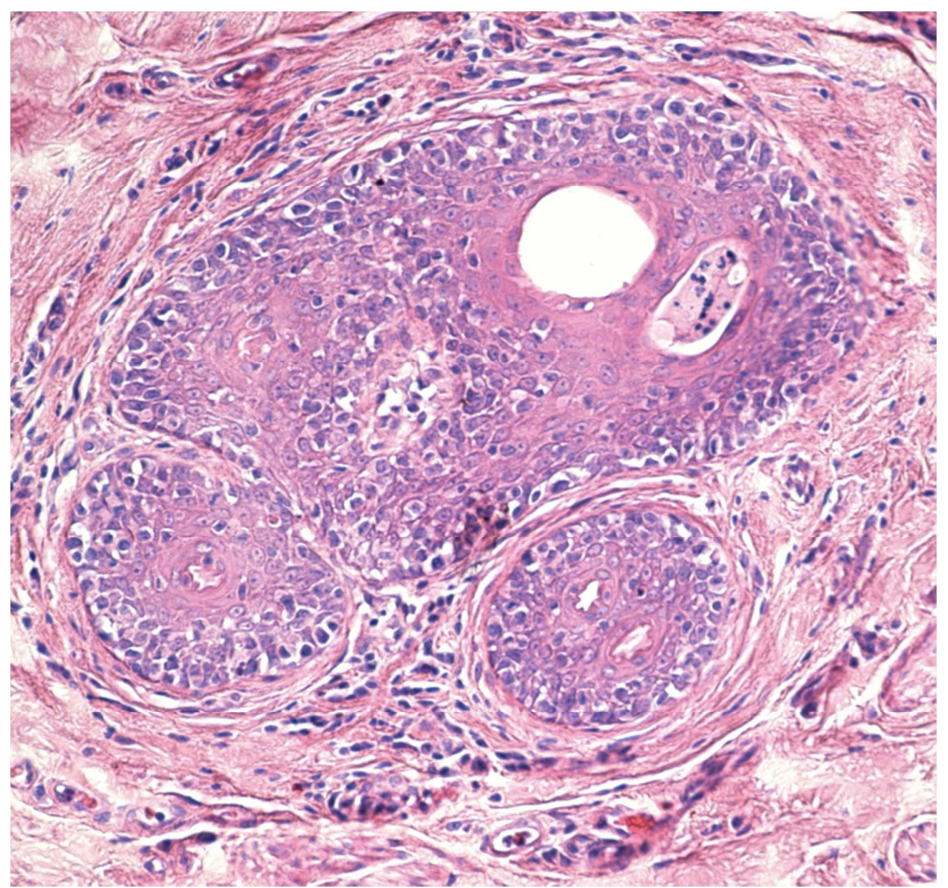

Figure 4. Annexes Pilosebaceous with Atypical Lymphocytic Infiltrate in the DermalEpidermal Interface Similar to that Observed in the Skin. HE 200X. 


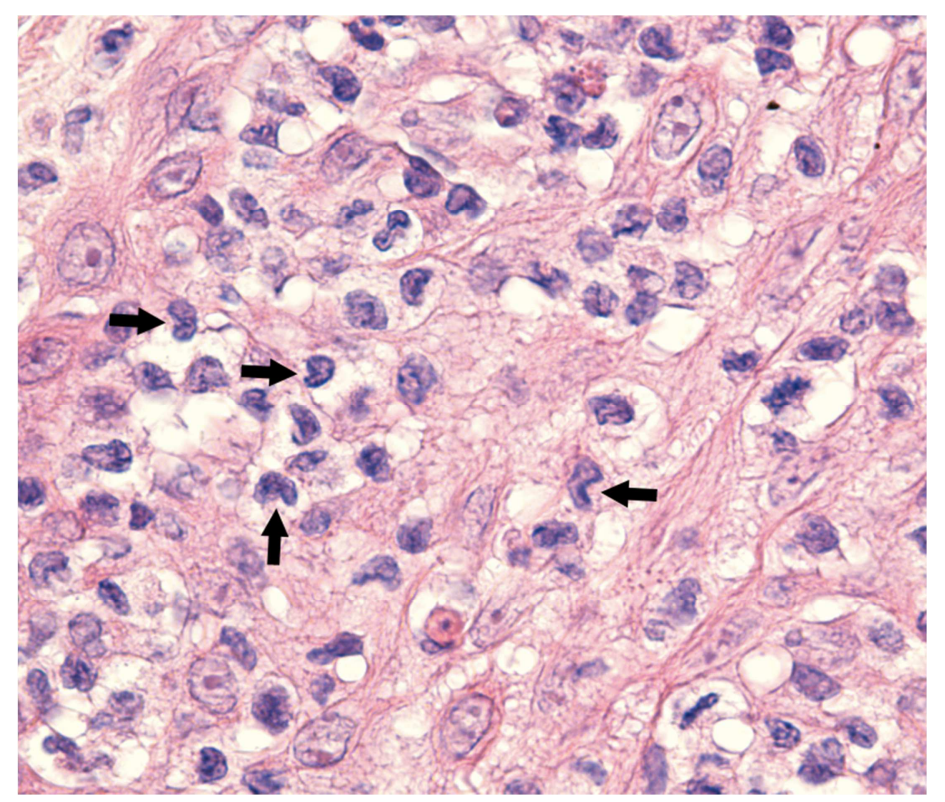

Figure 5. Large Increase Epidermal Infiltrate. Lymphoid Cells are Slightly Larger than a Normal Lymphocyte and Show Prominent Nuclear Grooves (Black Arrow). HE 1000X.

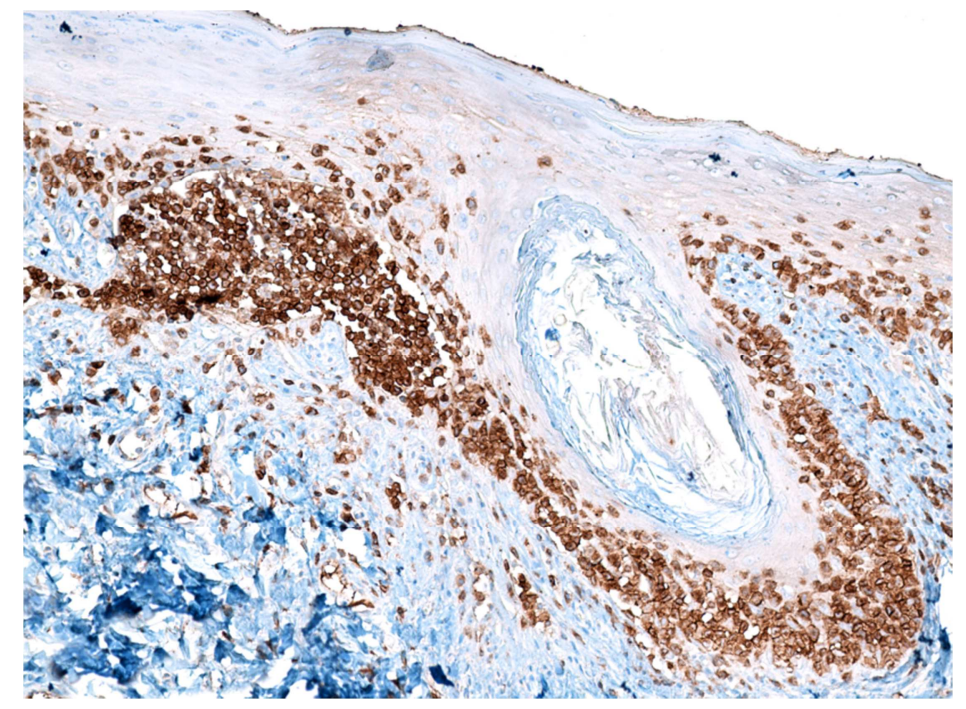

Figure 6. Immunohistochemistry for CD3 Antigen in Skin Biopsy. A Strong Positive Reaction Evidenced the Presence of CD3 T-cells. 10x. 


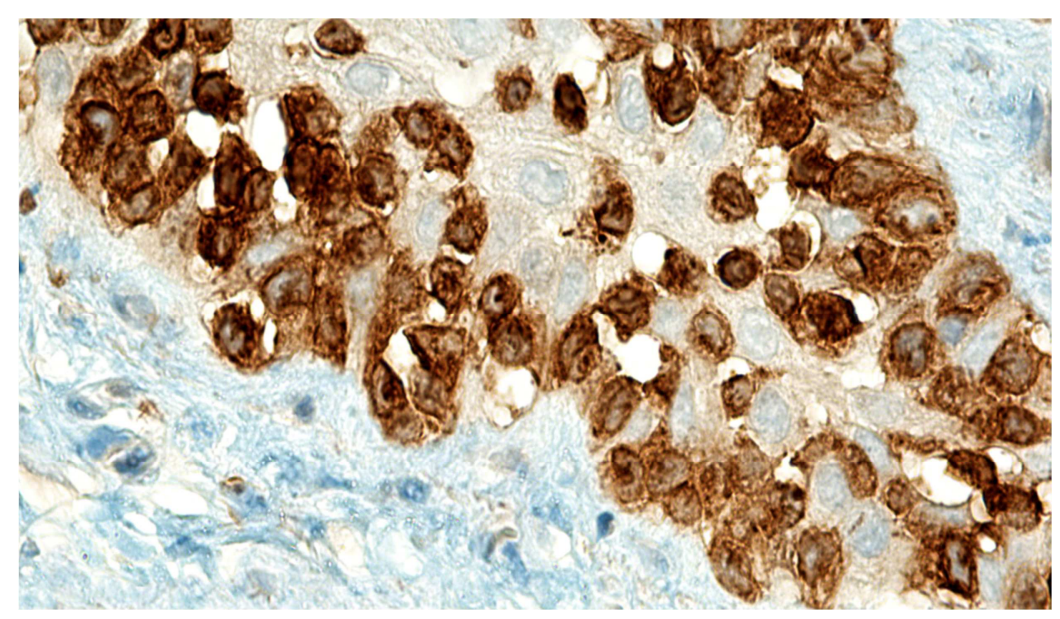

Figure 7. Detail of the Previous Photomicrograph where there are Strongly Positive CD3 Lymphocytes. Adjacent Negative Cells are Epidermal Keratinocytes. 1000X.

\section{Discussion}

In our case, for the first time in Colombia, an Epitheliotrophic Canine Cutaneous Tcell Lymphoma (CETL) is reported. CETL is a rare neoplasia of unknown etiology (Fournel-Fleury et al., 2002; Schmidt, 2011). The disease is characterized by a neoplastic T-cell infiltration with a special tropism toward the epidermis and related structures. The disease has 3 clinical forms: mycosis fungoides (MF), pagetoid reticulosis (PR) and Sezary syndrome (SS). Although lymphoma is a common neoplasia in dogs, this is not the case in cutaneous form, which represents only $5 \%$ of the overall canine lymphomas (Fournel-Fleury et al., 2002; Schmidt, 2011). Lymphoma occurs in adult dogs, older than 9 years, with no predilection for breed or gender (Fontaine et al., 2009; Scott et al., 2001). However, because of the most frequently detection in Boxer and Cocker spaniel, several authors have proposed that it depends on the predominant breeds in each country (Fontaine et al., 2009). Curiously, the present case, the patient was a 7 years old Golden retriever. The etiology of the disease is not clear, although abnormal Langerhans cell function (Weinstock and Horm, 1988) and the type C feline leukemia virus have been associated to the SS form in dogs (Safran et al., 1992). No association to the previous chronic dermatitis of the patient with CETL has been found (Shapiro and Pinto, 1994), but an association between CETL and other pathologies, such as previous atopic dermatitis, has been suggested (Santoro, 2007).

Clinical signs of CETL include single or multiple plaques of variable size from a few millimeters to several centimeters of diameter. Depigmentation of the mucocutaneous limits is also present, as well as ulcers in skin and mouth, where a severe stomatitis with generalized erythema, alopecia, intense pruritus and scratching has also been found. In some dogs, the digital pulps become hyper keratotic. When the disease progresses to chronicity, peripheral lymphadenomegaly and systemic disease are observed (Bhang et al., 2006; Hnilica and Medleau, 2011; Schmidt, 2011; Scott et al., 2001). This case presented clinical signs similar to those described by Foster et al (1997) (Foster et al., 1997), such as plaques, mucocutaneous lesions, severe pruritus and scratching, exfoliative erythrodermia, alopecia and wet skin with sero-purulent secretion (Figure 1). In addition, the present case exhibited clinical signs of systemic disease, broncopneumonia and fever for the last month of life.

Sezary syndrome is characterized by dermatological clinical signs accompanied with lymphocytic and neutrophilic leukocytosis $\left(59.000 / \mathrm{mm}^{3}\right.$ ) (Ghernati et al., 1999). This case showed several 
dermatological signs that were further confirmed by histopathology, including fungoid mycoses and a progressive increase of leukocyte counts until neutrophilia with left deviation, anemia and hypoproteinemia, but normal platelet count. Creatinine and BUN values were always found within the normal range, whereas alkaline phosphatase (ALP) and ALT values proportionally increased with skin and general compromise (Tables 1 and 2). Microscopic findings consist in lymphoproliferative lesions in epidermis with variable collections of atypic lymphocytes (Pautrier's micro abscesses). Contrary to human mycosis fungoides, in dogs lesions the lymphocytes are CD8+ and frequently exhibit a severe compromise of eccrine and pilous annexes with no associated mucinosis. Interestingly, there were not any intra-cytoplasmic granules or clear cytoplasm in $\mathrm{T}$ cells, so excluding a granular or monocytoid T-cell lymphoma. Frequently, the nucleus is small, without nucleolus and angled (Fontaine et al., 2009). As above-mentioned, the skin lesion of this case predominantly showed CD3+ Tcells, but also as mentioned, in peripheral blood smears performed during medical evaluations no Sezary`s cells were observed, suggesting Sezary syndrome. Monoclonal antibodies directed against human CD8 T-cells were also tested, but no signal was detected.

\section{Differential Diagnosis}

If the patient presents exfoliative erythrodermia, the differential diagnosis may include canine sarcoptic mange, atopic dermatitis, food adverse reactions, vasculitis, alteration of keratinization and Leishmaniasis, and in case of individual or multi-nodular plaques, differential diagnosis may include skin neoplasia, infection and hystiocytosis. If mucocutaneous lesions are detected, the diagnosis may include lupus erythematous, mucocutaneous pyoderm, vulgar pemphigus, paraneoplasic pemphigus, subepidermal paraneoplasic diseases, erythema multiform and complex vasculitis. Finally, if the dog exhibits oral ulcers, differential diagnosis may include autoimmune pemphigus and chronic stomatitis (Schmidt, 2011). In the present case, an acute pyoderm was considered in the initial differential diagnosis based on findings of a skin cytology compatible with Staphylococcus psuedointermedius and Malassezia pachidermatis infection, and as a result of the disseminated sero-purulent secretion found in the skin. The smear did not reveal the presence of mites. In addition, hormonal tests gave no related results (In fact, the patient was sprayed for avoiding the potential deleterious effect of estrogens in the skin) (Table 2). When a definitive diagnosis was reached, the patient was treated with several medications that may cause a significant toxicity in the skin and in different organs. Therefore, you must have knowledge in Internal Medicine and Dermatology diagnoses to establish a rapid and therefore adequate treatment for an established patient prognosis and survival thereof.

The prognosis for patients suffering CETL is poor and it is important to define subtypes present in an affected dog in order to established survival times. The mean survival time vary from 2 months to 2 years (Scott et al., 2001). In early diagnosis of dogs presenting patches or plaques, survival time ranges from 8 to 12 months (de Lorimier, 2006), although an average survival time up to 6 months after a definite diagnosis was proposed (Fontaine et al., 2010). This case was attended after a 4 month period of unsuccessful treatment elsewhere and the patient died 4 month after our treatment schedules had begun.

Treatment of CETL must be focused on palliative management of pain and pruritus, although some patients did not respond to this therapy. In fact, some practitioners did consider euthanasia as a choice because of humanitarian reasons (Schmidt, 2011). The myelosuppressive agent lomustine (CCNU) has been used for treatment of CETL, resulting in a 106 days average remission time in $78 \%$ of patients, and $16 \%$ overall remission in the affected dogs (Williams et al., 2006). Other study reported $83 \%$ overall remission with a 94 days average remission time (Risbon et al., 
2006). The use of retinoids during two months has resulted in partial remission of signs in $50 \%$ of patients when combined with prednisone for the treatment of pruritus and topic chemotherapy (Ettinger, 2003). In the present case did not respond to antibiotics, analgesia and topic shampooing, and when treated with triamcinolone, the patient presented a remission only for a short period of time (3 weeks), followed by a severe relapse of signs.

Surgical excision of unique lesions must be accompanied with chemotherapy or topic treatment with glucocorticoids (GC), mecloretamin, carmustin, retinoids, and imiquimod (de Lorimier, 2006). Other chemotherapeutic agents used in addition to lomustine are GC, mainly as coadjuvants; L-asparaginase, dacarbazin and doxorubicin with no concluding results. When a combined chemotherapy is used such as cyclophosphamide, doxorubicin, vincristine, and prednisone-, the remission rates range from $30 \%$ to $50 \%$ (de Lorimier, 2006). When a definite diagnosis of mycosis fungoides was established in this case, the patient presented a severe episode of bronchopneumonia before starting chemotherapy, and died 15 days later.

\section{Conclusions}

There is a wide range of clinical signs in CETL, including from the distinctive skin lesions to relevant hematological disorders not observed in other skin diseases which can be established as differential diagnosis. In Colombia, this neoplasia is not identified, either by a little knowledge, lack of reporting or because it is not really a common pathology, so it is therefore important to state that the abovementioned neoplasia can be observed in the routine veterinarian visit and that there is a need to have diagnostic criteria available allowing clinicians to get ready a presumptive diagnosis and that the appropriate diagnostic measures are taken in order to establish quick diagnosis, and therefore, predictions and possible treatments for giving quality of life to the patients affected by this pathology

\section{Acknowledgements}

INCA-CES research group activities are funded by CES University (Medellin, Colombia). Authors thank Dr. Juan Maldonado-Estrada (University of Antioquia) for critical reviewing of the manuscript.

\section{References}

Ackerman, L. J. (2008). "Atlas de Dermatología en Pequeños Animales," Inter-Médica, Buenos Aires.

Bhang, D. H., Choi, U. S., Kim, M. K., Choi, E.H., Kang, M.- S., Hwang, C.-Y., Kim, D.- Y., Youn, H. Y. \& Lee, C.W. (2006). "Epitheliotropic Cutaneous Lymphoma (Mycosis Fungoides) in a Dog," Journal of Veterinary Science 7, 97-99.

De Lorimier, L.- P. (2006). "Updates on the Management of Canine Epitheliotropic Cutaneous T-Cell Lymphoma," Veterinary Clinics of North America: Small Animal Practice 36, 213-228.

Ettinger, S. N. (2003). "Principles of Treatment for Canine Lymphoma," Clinical Techniques in Small Animal Practice 18, 9297.

Fogel, Y. M. \& Manzuc, P. (2009). 'Dermatología Canina para la Práctica Clínica Diaria,' Intermedica, Buenos Aires.

Fontaine, J., Bovens, C., Bettenay, S. \& Mueller, R. S. (2009). "Canine Cutaneous Epitheliotropic T-Cell Lymphoma: A Review," Veterinary and Comparative Oncology 7, 1-14.

Fontaine, J., Heimann, M. \& Day, M. J. (2010). "Canine Cutaneous Epitheliotropic T-Cell Lymphoma: A Review of 30 Cases," Veterinary Dermatology 21, 267-275.

Foster, A. P., Evans, E., Kerlin, R. L. \& Vail, D. M. (1997). "Cutaneous T-Cell Lymphoma with Sézary Syndrome in a Dog," Veterinary Clinical Pathology 26, 188-192. 
Fournel-Fleury, C., Ponce, F., Felman, P., Blavier, A., Bonnefont, C., Chabanne, L., Marchal, T., Cadore, J. L., Goy-Thollot, I., Ledieu, D., Ghernati, I. \& Magnol, J. P. (2002). "Canine T-Cell Lymphomas: A Morphological, Immunological, and Clinical Study of 46 New Cases," Veterinary Pathology 39, 92-109.

Ghernati, I., Auger, C., Chabanne, L., Corbin, A., Bonnefont, C., Magnol, J. P., Fournel, C., Rivoire, A. \& Monier, J. C., Rigal, D. (1999). "Characterization of a Canine Long-Term T Cell Line (DLC 01) Established from a Dog with Sézary Syndrome and Producing Retroviral Particles," Leukemia 13, 12811290.

Harvey, R. G. \& McKeever, P. J. (2001). 'Manual Ilustrado de Enfermedades de la Piel en Perro y Gato,' EDIMSA, Madrid.

Hnilica, K. A. \& Medleau, L. (2011). 'Small Animal Dermatology: A Color Atlas and Therapeutic Guide,' Elsevier/Saunders, St. Louis, Mo.

Medleau, L., Hnilica, K. A., Fagliari, J. J. \& Fagliari, G. S. (2003). 'Dermatologia de Pequenos Animais: Atlas Colorido e Guia Terapêutico,' Roca, São Paulo.

Risbon, R. E., de Lorimier, L. P., Skorupski, K., Burgess, K. E., Bergman, P. J., Carreras, J., Hahn, K., Leblanc, A., Turek, M., Impellizeri, J., Fred, R., 3rd, Wojcieszyn, J. W., Drobatz, K. \& Clifford, C. A. (2006). "Response of Canine Cutaneous Epitheliotropic Lymphoma to Lomustine (CCNU): A Retrospective Study of 46 Cases (19992004)," Journal of Veterinary Internal Medicine 20, 1389-1397.

Safran, N., Perk, K. \& Eyal, O. (1992). "Isolation and Preliminary Characterisation of a Novel Retrovirus Isolated from a Leukaemic Dog," Research in Veterinary Science 42, 250-255.

Schmidt, V. (2011). "Epitheliotropic T-Cell Cutaneous Lymphoma in Dogs," Companion Animal 16, 49-54.
Scott, D. W., Muller, G. H., Kirk, R. W., Miller, W. H. \& Griffin, C. E. (2001). 'Muller \& Kirk's Small Animal Dermatology,' W.B. Saunders, Philadelphia.

Shapiro, P. E. \& Pinto, F. J. (1994). "The Histologic Spectrum of Mycosis Fungoides/Sézary Syndrome (Cutaneous TCell Lymphoma). A Review of 222 Biopsies, Including Newly Described Patterns and the Earliest Pathologic Changes," American Journal of Surgical Pathology 18, 645-667.

Weinstock, M. A. \& Horm, J. W. (1988). "Mycosis Fungoides in the United States Increasing Incidence and Descriptive Epidemiology," JAMA, Journal american medical asociation 260, 4-46.

Williams, L. E., Rassnick, K. M., Power, H. T., Lana, S. E., Morrison-Collister, K. E., Hansen, K. \& Johnson, J. L. (2006). "CCNU in the Treatment of Canine Epitheliotropic Lymphoma," Journal of Veterinary Internal Medicine 20, 136-143. 